\title{
BIASING FIELD EFFECTS ON ELECTRONIC PROPERTIES IN HALOGENATED PHENYLENE ETHYNYLENE OLIGOMERS
}

\author{
Irina Petreska $^{1^{*}}$, Ljupčo Pejov ${ }^{2}$, Ljupčo Kocarev ${ }^{3}$ \\ ${ }^{1}$ Institute of Physics, Faculty of Natural Sciences and Mathematics, Ss. Cyril and Methodius University, \\ Skopje, Republic of Macedonia \\ ${ }^{2}$ Institute of Chemistry, Faculty of Natural Sciences and Mathematics, Ss. Cyril and Methodius University, \\ Skopje, Republic of Macedonia \\ ${ }^{3}$ Macedonian Academy of Sciences and Arts, Research Center for Energy, Informatics and Materials, \\ Skopje, Republic of Macedonia \\ *Corresponding author, e-mail: irina.petreska@pmf.ukim.mk
}

In this paper results from $a b$ initio simulations of the electronic structure properties of a class of halogenated phenylene ethynylene oligomers (OPE) are presented. These molecular species are investigated because of their suitable properties for application as single-molecule switches in the future emerging molecular electronic devices. Combined Hartree-Fock and Density Functional Theory approach is applied to investigate the biasing field effects on the relevant electronic properties, such as potential energy of the ground states, potential barrier height, localization of frontier molecular orbitals and the HOMO-LUMO gap. Special attention is also paid on the effects of substitution of the hydrogen atoms in the central phenylene ring of basic OPE molecule with halogen atoms. The analyses of the obtained results undoubtedly show that the biasing field has a strong impact on the potential barrier height, transition probabilities and band gap. Halogenation of the central phenylene ring does not have such a strong influence on the aforementioned properties, but it could be a useful way for fine tuning of some of the properties, especially the potential barrier height, enabling control of the torsional stochastic switching, inherent for the studied species.

Key words: ab initio; phenylene ethynylene; single-molecule switches; Hartree-Fock; Density Functional Theory; potential barrier; frontier molecular orbitals; HOMO-LUMO gap; torsional stochastic switching

\section{INTRODUCTION}

As the limit of miniaturization and operability capacities of semiconducting electronic devices have been reached, the tendency toward eversmaller size, results in extensive studies of a singlemolecule electronic properties. There is already a remarkable number of both, experimental and theoretical works in which the possibilities a single molecule to be employed as an electronic component have been investigated [1-10]. Development of novel molecular electronic devices is interplay between fundamental sciences, such as physics and chemistry, at one hand, and electrical engineering on the other. Starting from the late seventies of the past century, this led to a new interdisciplinary field, called molecular electronics or moletronics, which has been opened with the pioneer model of a molecular rectifier, proposed by Aviram and Ratner $[1,2]$. These ideas were further developed in numerous works [3-10, to name but a few]. Quantum mechanical effects must be taken into account in the electronic structure treatment on a molecular scale, and thus, the investigations of the quantum mechanical properties relevant to electron transport in single molecules and stability of molecular devices, such as localization of frontier molecular orbitals, potential energy surface, tunneling probabilities, etc. are of fundamental importance.

So far, various molecular classes, including acyclic, cyclic and polycyclic hydrocarbons; C-materials (carbon nano-tubes, fulerenes, graphene based 
structures); DNA and its derivatives have been the subject of investigation. Speaking in general, the organic oligomers, especially the ones based on phenylene rings are among the most promising candidates for molecular electronics. Possessing bistability, delocalized molecular orbitals, appropriate and controllable gap between the Highest Occupied Molecular Orbital (HOMO) and Lowest Unoccupied Molecular Orbital (LUMO), is what makes them suitable to be applied as electronic devices.

The present paper deals with the phenylene ethynylene oligomers and its halogenated derivatives. We investigate the electric field effects on the potential barrier heights, delocalization of frontier molecular orbitals and the HOMO-LUMO gap for the halogenated OPE oligomers, where hydrogen atoms in the central phenylene ring are substituted by halogen ones $(\mathrm{F}, \mathrm{Cl}, \mathrm{Br}, \mathrm{I})$. These molecules posses bistability since they can be found in two stationary states, recognized as planar and perpendicular

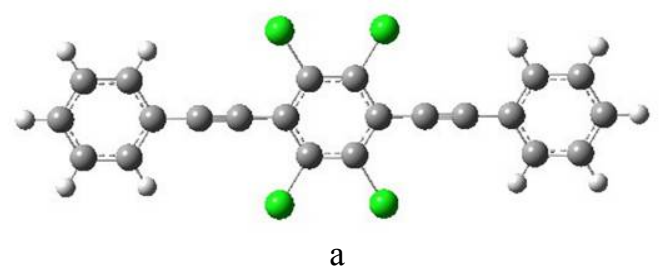

(Figure 1), respectively. Switching between these two states, with clearly distinguishable conductivity one from another, in a molecule bound to electrodes is most likely to occur as a result of torsional oscillations of the central phenylene ring $[3,4,7,11]$. In the present paper we are particularly focused on computational investigations of the HOMO-LUMO gap and the biasing field effects on it. Electric field effects on several other properties such as potential barrier height and transition probability have been also investigated and are briefly commented later on. The HOMO-LUMO gap is directly related to the molecular conductivity, since the highest occupied molecular orbital is an analogue to the valent zone in semiconducting devices, and the lowest unoccupied orbital could be identified as a conducting zone. Thus, tuning the energy difference between these orbitals is of substantial importance for molecular impedance.

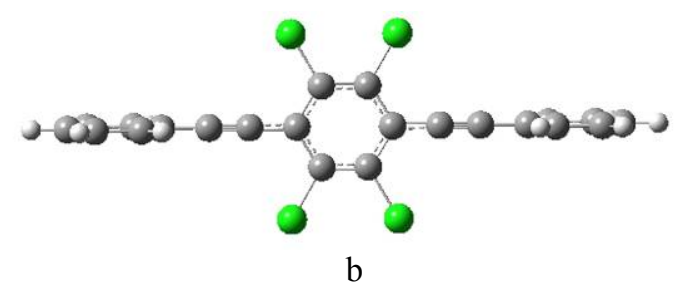

Figure 1. Optimized configurations of perhalogenated OPE oligomers. The hydrogen atoms in the central phenylene ring are substituted by halogen elements (F, Cl, Br, I). Two stationary points are found on the potential energy surface: a) optimized configuration representing a global minimum of the potential energy surface, denoted as planar conformer throughout the text, b) second order saddle point representing a metastable state, denoted as perpendicular conformer throughout the text. The two imaginary frequencies, corresponding to the second order saddle point for the represented oligomer (chlorinated OPE) are $-7.165 \cdot 10^{11} \mathrm{~Hz}$ and $-6.284 \cdot 10^{11} \mathrm{~Hz}$. These values are approximately the same for the rest of the considered derivatives.

Also, shifting of the frontier molecular orbitals towards the Fermi level when the molecule is attached to metallic electrodes is one of the biggest problems for current flow through single molecules. In this work we investigate the effects of the halogenation of the OPE molecules, as well as the effect of an electric field, with an orientation coinciding with the biasing field of the prospective device on the HOMO-LUMO gap, applying firstprinciples molecular orbital theory. In our previous related papers we have analyzed the orbitals shifting, that was solely due to perhalogenation of the central phenylene ring, studying different halogen substituents $[7,11]$. We have also studied the electric field effects on the non-substituted OPE molecule. Here we extend the investigation, by analyzing the electric field effects on the halogenated OPE derivatives, by explicit inclusion of the field in the many-body Hamiltonian. Our results show that fine tuning of the HOMO-LUMO gap, as well as shifting of the frontier molecular orbitals, which is crucial for charge transfer via single particle states, can be successfully modulated by the biasing field.

\section{THEORETICAL BACKGROUND}

The computational methodology applied for electronic structure calculations in the present paper is based on a hybrid Hartree-Fock/Density Functional Theory (HF/DFT) approach. In this section we only give short outlines of the most important features of these methods. It is well known that the problem of exact solution of the Schrödinger equation for the polyatomic molecular species, related with the presence of the two-particle operators in the manybody Hamiltonians, in first approximation is overcome within the mean field theory approach (HF self-consistent field). The two-particle interactions 
are modeled as an interaction of each electron with the mean field that is due to all other electrons, enabling substitution of the two-particle operators with one-particle operators, depending only on the position of the considered electron. This assumption transforms the $n$-electron equation to $n$ oneelectron equations. That is, the wave function can be expressed as a product of $n$ one-electron wave functions (orbitals), each being solution of oneelectron Hamiltonian. For details about HF methods see for example [12, 13 and references therein].

The basic idea behind the DFT methods, arising from the Hohenberg-Kohn theorem is that the energy of an electronic system can be expressed in terms of the electron probability density. Thus the electronic energy can be considered as a functional of the electronic density in a sense that for a given electron density, there's a single corresponding energy $[12,13]$. The main goal of the DFT methods is to obtain the electron density function. The Kohn-Sham equations, having one-electron spatial orbitals (KohnSham orbitals) as solutions are very frequently used for that purpose. The ground-state electronic energy of $n$-electronic system can be expressed in terms of the Kohn-Sham orbitals as follows:

$$
E[\rho]=-\frac{\hbar}{2 m_{e}} \sum_{i=1}^{n} \int \psi_{i}^{*}\left(r_{1}\right) \nabla_{1}^{2} \psi_{i}\left(r_{1}\right) d r_{1}-j_{0} \sum_{I=1}^{N} \frac{Z_{I}}{r_{I 1}} \rho\left(r_{1}\right) d r_{1}+\frac{1}{2} j_{0} \int \frac{\rho\left(r_{1}\right) \rho\left(r_{2}\right)}{r_{12}} d r_{1} d r_{2}+E_{X C}[\rho],
$$

where $\psi_{i}$ are the Kohn-Sham orbitals and $E_{X C}$ is the exchange-correlation energy of the system, which is also a functional of the electron density and takes into account all non-classical electron-electron interactions. There is a large number of schemes for obtaining the functional for the exchange-correlation energy, and the search for more accurate functional is still active area of research $[12,13]$.

\section{COMPUTATIONAL DETAILS}

For the purposes of this work we have employed the methodology based on the densityfunctional theory (DFT) combined with the HF self-consistent field methods, tested and implemented in the frames of our previous works $[7,11]$. A combination of the Becke's three parameter adiabatic connection exchange functional (B3, [15]) with the Lee-Yang-Parr correlation one (LYP, [16]) was used. The Kohn-Sham SCF equations were iteratively solved by an orbital expansion in the LANL2DZ basis set (Los Alamos ECP plus DZ on Na-Bi) [17]. Ultrafine grid was used for the numerical integration in all DFT calculations. Geometry was optimized by applying the Schlegel's gradient algorithm [18]. The calculations for the single-molecule were carried out by GAUSSIAN 03 series of computer codes [19].

Being interested especially in the changes that biasing field would cause on the frontier molecular orbitals, in this work we analyze the orientation of the field along the major molecular axis ( $z$-axis) which coincides with the biasing field direction. Field strengths within interval from 0.000 to 0.010 atomic units $\left(1\right.$ a.u. $\left.=5.14 \cdot 10^{11} \mathrm{~V} / \mathrm{m}\right)$ were explicitly included in the many-body Hamiltonian. Having in mind that the molecular devices are intended to be used at voltages of an order of $1 \mathrm{~V}$ and estimating the dimensions of the device with the molecular length, the aforementioned values are of the same order of magnitude exerted by the applied bias voltage. In our previous work we have also considered stronger field magnitudes and various field orientations in regard of analyzing control of the torsional stochastic switching with fields additional to the biasing one.

From the first principles calculations we obtain the ground energy of the conformers, the HOMOLUMO gap and delocalization of the orbitals. We further use the energy difference between the planar and perpendicular structure of the conformers to find the potential barrier height, which governs the torsional stochastic oscillations. The potential barrier height is further used to evaluate the transition probability between the aforementioned states. Extensive analysis of the methodology and computational details regarding the calculation of the transition probability is presented in our previous works [7, 14].

\section{RESULTS AND DISCUSSION}

The fully optimized geometries of the two stationary points, from which the planar one is a global minimum and the perpendicular is a secondorder saddle point are given in Figure 1. Frontier molecular orbitals of the planar conformer of the halogenated OPE molecules are fully delocalized (Figure 2, $a$ and $b$ ). The presented figures are for chlorinated OPE, but results are rather similar with other studied substituents. Delocalization of frontier 
orbitals is one of the presumptions for high conductance. For the perpendicular conformer, the electron localization and conductance switching is obvious from Figure 2, (c and d). Substituting hydrogen atoms with halogen ones, localizes the electrons in the HOMO orbital of the perpendicular conformer to the lateral rings, which is the only notable difference with respect to the basic OPE [14].

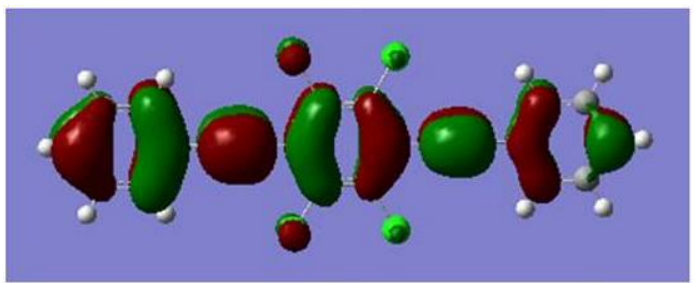

a

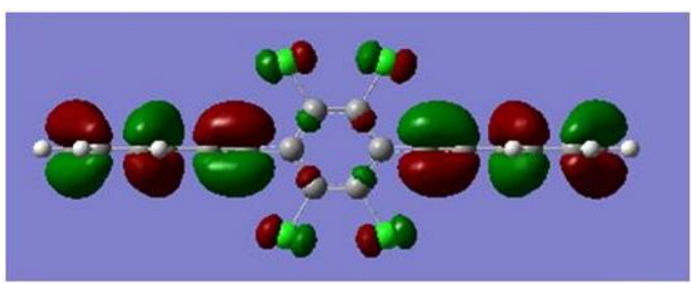

c

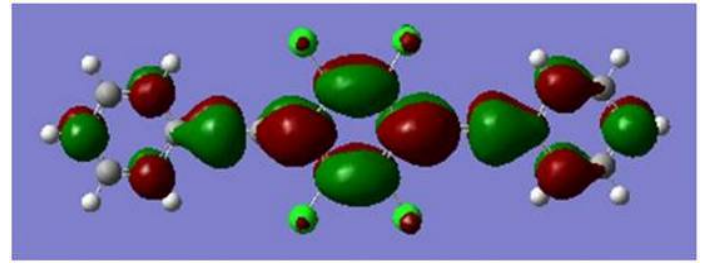

b

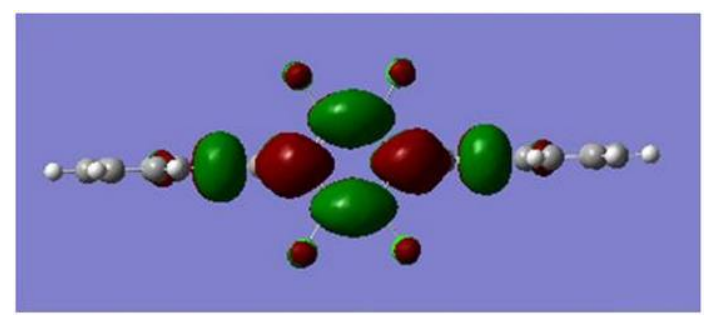

d

Figure 2. Delocalization of the frontier molecular orbitals in the chlorinated OPE.

a) HOMO for the planar conformer; b) LUMO for the planar conformer;

c) HOMO for the perpendicular conformer; d) LUMO for the perpendicular conformer

Together with the delocalization of molecular orbitals, the HOMO-LUMO gap (HLG) is another property, important for the conductivity. The lower the HLG, the greater the conductivity. The presence of halogen atoms in the central phenylene ring in a free oligomer (out of external electric field) decreases the HLG, and at the same time it has no significant effects on delocalization of the frontier molecular orbitals. The plots for the HLG versus electric field magnitude is comparatively represented for both, substituted and nonsubstituted OPE molecules (Figures 3 and 4).

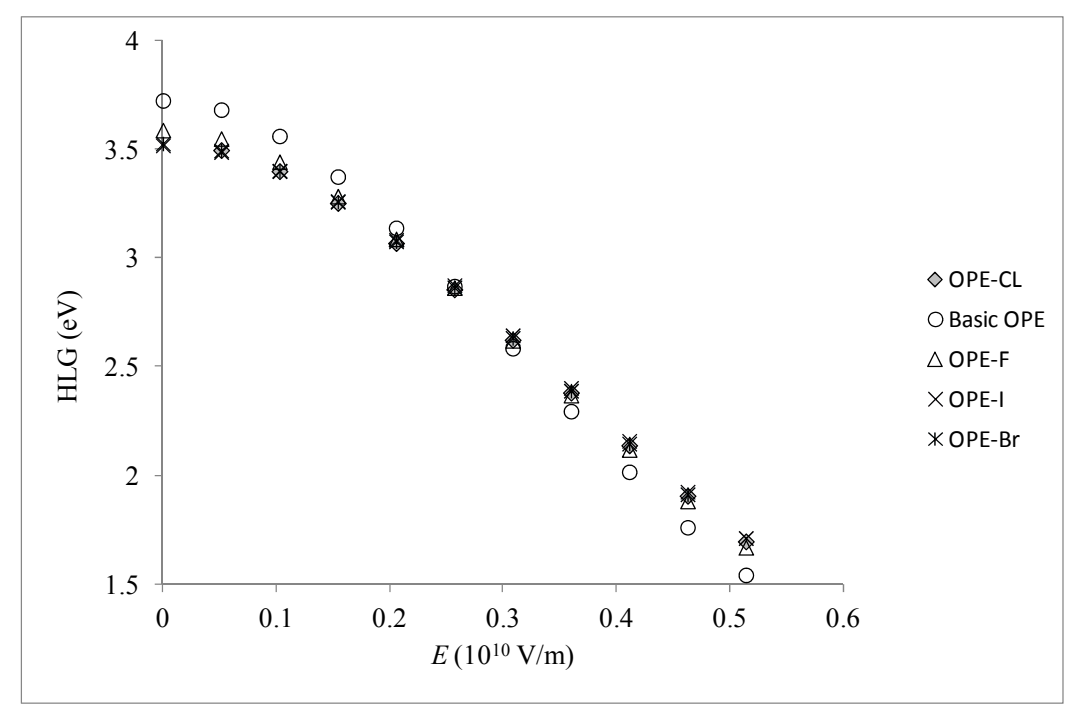

Figure 3. The HOMO-LUMO gap vs. electric field for planar conformation of the basic and halogenated OPE molecules 


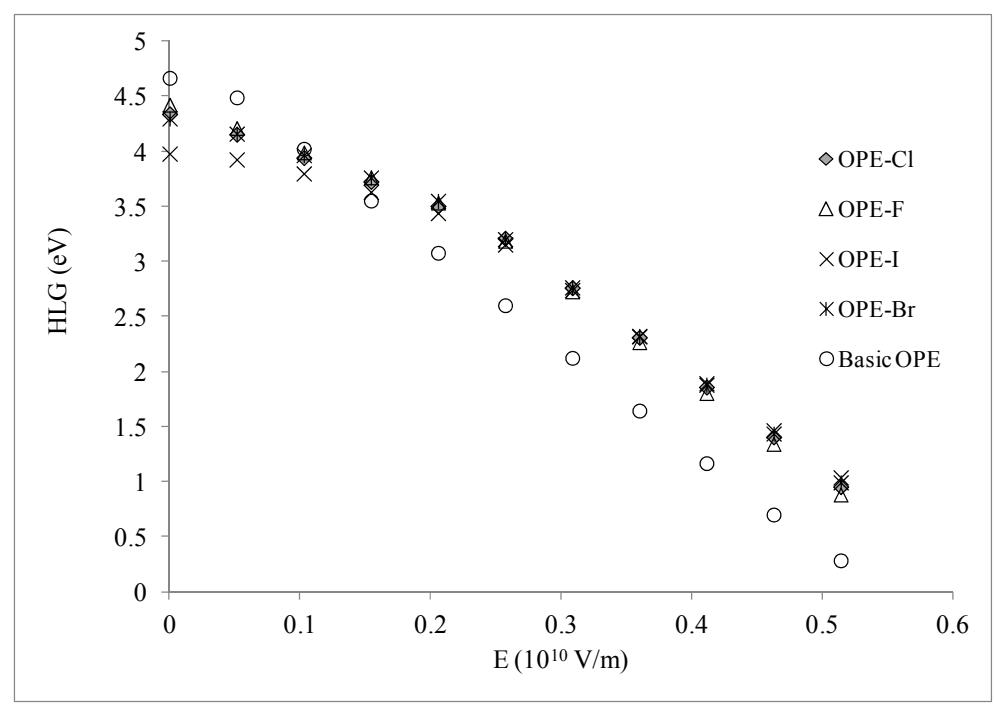

Figure 4. The HOMO-LUMO gap vs. electric field for perpendicular conformer of the basic and halogenated OPE molecules

As the magnitude of the field along $z$-axis increases, the HLG decreases. Decrease in the HLG at zero field and lower magnitudes is most obvious in periodinated and perbrominated derivatives, and as the field increases the HLG values become nearly equal for all substituted derivatives. As shown in our previous work [13], the dependence in the case of field oriented along the main axis, is more complex, so that the HLG decreases to some value, and then it increases at higher field magnitudes. From the plots obtained in this work one can conclude that the field effects on the HLG are similar for both, substituted and non-substituted OPE, manifesting somewhat steeper HLG decrease in the case of the basic OPE. Thus, starting from certain field magnitude the HLG for the basic OPE HLG gains lower value than for the substituted ones. Note that higher of the perpendicular conformers with respect to the planar ones is another important prerequisite for lower conductivity or complete conductance switching. The electric field has influence on energies of both, HOMO and LUMO orbitals, shifting them towards lower values. However, the decrease of the HUMO-LUMO gap results primarily by shifting of the LUMO orbital closer to HOMO. Perhalogenation of the central phenylene ring leads to decrease of the HLG, which means enhancement of the molecular admittance. If we compare the trends of the HLG vs. field in non-substituted and substituted derivatives it is seen that the per-halogenation of the central phenylene ring reduces the HLG by nearly the same amount as the electric field of around $2 \cdot 10^{9} \mathrm{~V} / \mathrm{m}$ applied to a non-substituted sample. As the molecular electronic devices are intended to be used under lower bias voltages, the advantage of per-halogenation is that it enables significant decrease of the HLG gap with respect to the non-substituted OPE even at lower field magnitudes. Further more in the paper of Pejov et al. [7] it was shown that the perhalogenation also leads to obvious stabilization of the torsional stochastic oscillations, by increasing the life time, transition probability and potential barrier height. Figures 5 and 6 illustrate the field effects on the potential barrier heights and classical transition probability that are in fact governed by the barrier height. Evidently the biasing field by modulating the potential barrier height reduces the transition probability leading to control of the torsional stochastic switching. Stronger electric fields oriented perpendicularly to the biasing field enable fine tuning and control of the thermally induced stochastic switching in a more subtle manner, as it was shown in the aforementioned paper [14].

To conclude, in the present paper a first principles study of the electronic properties of halogenated OPE oligomers embedded in an electric field, applied to model the biasing field was carried out. It was shown that these oligomers are suitable for future applications as single-molecules switches. The biasing field decreases the HOMO-LUMO gap which leads to enhancement of the conductance in the conductive planar conformer. Also, the biasing field reduces the transition probability, by increasing the potential barrier height, which is important for stabilizations of the conductive molecular configuration. 


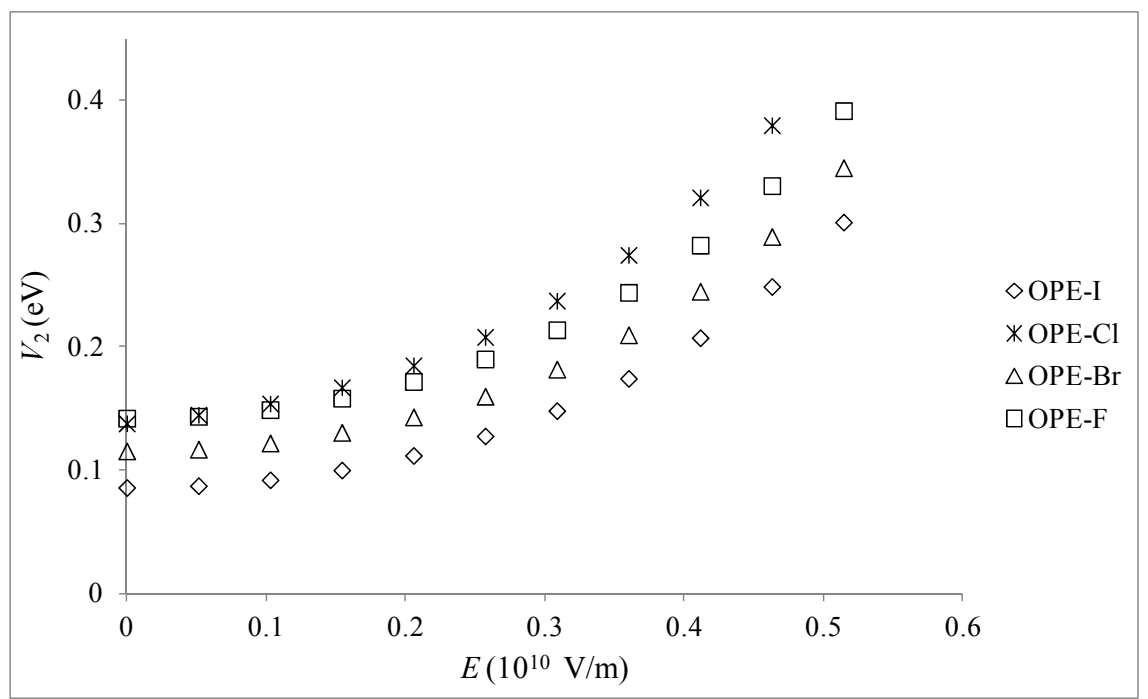

Figure 5. Electric field influence on the potential barrier height in iodinated (OPE-I), chlorinated (OPE-Cl), brominated (OPE-Br) and fluorinated (OPE-F) phenylene ethynylene oligomers, respectively.

The electric field $E$ is expressed in $\mathrm{V} / \mathrm{m}$ and the potential barrier height $V_{2}$ in $\mathrm{eV}$

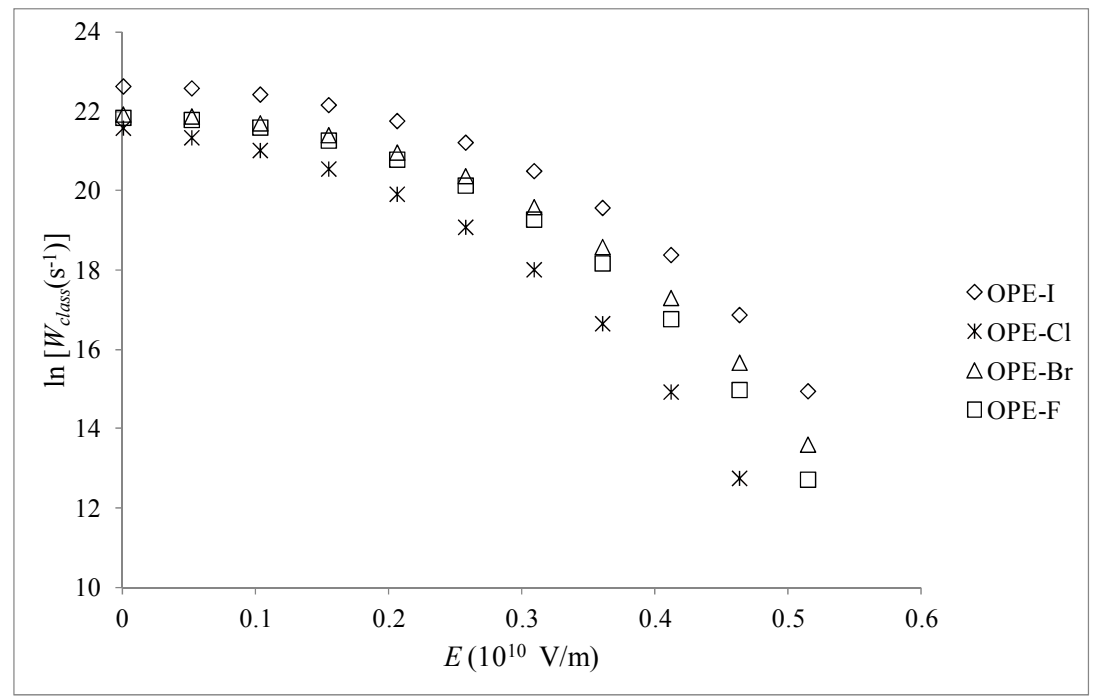

Figure 6. Electric field influence on the classical transition probability in iodinated (OPE-I), chlorinated (OPE-Cl), brominated (OPE-Br) and fluorinated (OPE-F) phenylene ethynylene oligomers, respectively

\section{REFERENCES}

[1] A. Aviram, M. A. Ratner, Molecular rectifier, Chem. Phys. Lett. 29 (1974), pp. 277-283.

[2] A. Aviram, M. A. Ratner, Molecular Electronics, II, New York Academy of Sciences, New York, 1998.

[3] Z. J. Donhauser, B. A. Mantooth, K. F. Kelly, L. A. Bumm, J. D. Monnell, J. J. Stapleton, D. W. Price Jr., A. M. Rawlett, D. L. Allara, J. M. Tour and P. S. Weiss, Conductance switching in single molecules through conformational changes, Science, 292 (2001), pp. 2303-2307.

[4] J. M. Seminario, P. A. Derosa and J. L. Bastos, Theoretical interpretation of switching in experi- ments with single molecules, J. Am. Chem. Soc 124.(2002), pp. 10266-10267.

[5] B. A. Mantooth and P. S. Weiss, Fabrication, assembly and characterization of molecular electronic components, Proceedings of the IEEE, 91 (2003), pp.1785-1802.

[6] A. Hallback, B. Poelsema, H. J. W. Zandvliet, Dynamics of stochastic conductance switching of Phenylene-Ethynylene Oligomers, ChemPhysChem, 8 (2007), pp. 661-665.

[7] Lj. Pejov, M. La Rosa, Lj. Kocarev, Dynamics of the central phenylene ring torsional motion in halogenated Phenylene Ethynylene Oligomers, Chem. Phys., 340 (2007), pp. 1-11. 
[8] A. Troisi, M. A. Ratner, Molecular rectification through electric field induced conformational changes, J. Amer. Chem. Soc., 124 (2002), pp. 14528-14529.

[9] A. Troisi, M. A. Ratner, Conformational molecular rectifiers, Nanolett., 4 (2004), pp. 591-595.

[10] P. E. Kornilovich, A. M. Bratkovsky, R. S. Williams, Bistable molecular conductors with a field-switchable dipole group, Phys. Rev. B, 66 (2002), 245413(7).

[11] Lj. Pejov, I. Petreska, M. La Rosa, Lj. Kocarev, Dynamics of the central phenylene ring torsional motion in Phenylene Ethynylene Oligomers: A quantum-theoretical study of single-molecule switching phenomena, Advanced micro- and mesoporous materials, Proceedings of the Second International Symposium, Varna, Bulgaria, 6-9 September 2007, Heron Press - Sofia, MMVIII (2008), pp. 51-59.

[12] R. G. Parr and Weitao Yang, Density Functional Theory of Atoms and Molecules, Oxford University Press, 1989.
[13] P. Atkins, R. Friedman, Molecular Quantum Mechanics, Fourth Edition, Oxford University Press, 2005.

[14] I. Petreska, Lj. Pejov and Lj. Kocarev, Controlling the torsional stochastic switching in OPE molecules by external electrostatic fields, Phys. Rev. B 78 (2008), 045209(5).

[15] A. D. Becke, Density-functional exchange-energy approximation with correct asymptotic behavior, Phys. Rev. A, 38 (1988), pp. 3098-3100.

[16] C. Lee, W. Yang and R. G. Parr, Development of the Colle-Salvetti correlation-energy formula into a functional of the electron density, Phys. Rev. B, 37 (1988), pp. 785-789.

[17] T. H. Dunning Jr. and P. j. Hay, Gaussian basis sets for molecular calculations, in Methods of Electronic Structure Theory, Modern Theoretical Chemistry 3, Ed. H. F. Schaefer (1977), pp. 1-27.

[18] H. B. Schlegel, Optimization of equilibrium geometries and transition structures, J. Comp. Chem., 3 (1982), pp. 214-218.

[19] Gaussian 03 (Revision B.03), M. J. Frisch et al., Gaussian, Inc., Pittsburgh PA, 2003.

\title{
ЕФЕКТИТЕ ОД НАДВОРЕШНО ЕЛЕКТРИЧНО ПОЛЕ ВРЗ ЕЛЕКТРОНСКИТЕ СВОЈСТВА НА ХАЛОГЕНИРАНИТЕ ФЕНИЛЕН ЕТИНИЛЕН ОЛИГОМЕРИ
}

\author{
Ирина Петреска ${ }^{1}$, Љупчо Пејов ${ }^{2}$, Љупчо Коцарев ${ }^{3}$ \\ ${ }^{1}$ Институт за физика, Природно-математички факултет, Универзитет „Св. Кирил и Методиј“, \\ Скопје, Република Македонија \\ ${ }^{2}$ Институт за хемија, Природно-математички факултет, Универзитет „Св. Кирил и Методиј“, \\ Скопје, Република Македонија \\ ${ }^{3}$ Македонска академија на науките и уметностите, Истражувачки центар за енергетика, \\ информатика и материјали, Скопје, Република Македонија
}

Во овој труд се презентирани резултати од ab initio пресметки на електронската структура на една класа халогенирани фенилен етинилен олигомери. Овие молекулски видови се изучуваат поради нивните погодни својства за примена како молекулски прекинувачи во идните молекулски електронски уреди. Користен е комбиниран теоретски пристап, базиран на Хартри-Фок методот и методите на функционал од електронската густина за изучување на ефектите од електричното поле што се должи на приложениот напон врз електронските својства од интерес, како што се енергијата на основната состојба, висината на потенцијалната бариера, локализација на молекулските орбитали и НOMO-LUMO јазот. Особено внимание, исто така, е посветено и на ефектите од самата супституција на водородните атоми во централниот фениленски прстен со халогени атоми. Анализите на добиените резултати недвосмислено покажуваат дека надворешното напонско поле има силно влијание врз висината на потенцијалната бариера, веројатностите за премин и HOMO-LUMO јазот. Самата халогенизација на централниот фениленски прстен нема толку изразено влијание врз спомнатите својства, но сепак би можела да биде корисен начин за фино приспособување на некои од својствата, особено на висината на потенцијалната бариера, со што се овозможува контрола на стохастичните торзиони осцилации, својствени за овие олигомери.

Клучни зборови: ab initio; фенилен етинилен олигомери; молекулски прекинувачи; Хартри-Фок; функционал од електронската густина; потенцијална бариера; надворешни молекулски орбитали; НОМОLUMO јаз; стохастични торзиони осцилации 